\title{
Evaluation of Immunotoxicity of Shizukaol B Isolated from Chloranthus japonicus
}

\author{
Soon Woo Kwon ${ }^{1, a}$, Young Kook Kim ${ }^{2, a}$, Jee Youn Kim ${ }^{1, a}$, Hwa Sun Ryu ${ }^{1}$, Hong Kyung Lee ${ }^{1}$, Jong Soon Kang ${ }^{2}$, \\ Hwan Mook Kim ${ }^{2}$, Jin Tae Hong ${ }^{1}$, Youngsoo Kim ${ }^{1}$ and Sang-Bae Han ${ }^{1, *}$ \\ ${ }^{1}$ College of Pharmacy and Medical Research Center (CICT), Chungbuk National University, Cheongju 361-763, \\ ${ }^{2}$ Korea Research Institute of Bioscience and Biotechnology, Ochang 363-883, Republic of Korea
}

\begin{abstract}
Dimeric sesquiterpenoid shizukaol B (SKB) was isolated from Chloranthus japonicus Sieb. Except that SKB inhibited adhesion molecule expression in monocytes and endothelial cells, no more biological and pharmacological activity of SKB had been reported until now. In this study, we examined immunosuppressive activity of SKB. SKB strongly inhibited lipopolysaccharide (LPS)induced $B$ cell proliferation with $\mathrm{IC}_{50}$ of $137 \mathrm{ng} / \mathrm{ml}$, but slightly or not concanavalin A-induced T cell proliferation, LPS-induced macrophage NO production, and LPS-induced dendritic cell maturation. As a mechanism, SKB strongly induced apoptotic death of $B$ cells, but not other cell types. These results suggested that SKB induced toxicity-mediated immunosuppression against $B$ cells.
\end{abstract}

Key Words: Shizukaol B, Chloranthus japonicus, Immunosuppression, Cytotoxicity, B cells

\section{INTRODUCTION}

The genus Chloranthus has been taxonomically placed in the Chloranthaceae and has long been used as folk medicine for their antitumor, antifungal, and anti-inflammatory activities (Kuang et al., 2008). The components of genus Chloranthus are volatile oil, simple coumarins, amide alkaloids and sesquiterpene lactones having a lindenane skeleton named shizukanolides and chloranthalactones (Kuang et al., 2009). Chloranthus japonicus is a perennial herb that grows in the southern part of Korea, Japan, and China (Kwon et al., 2006). As a biologically active substance from this plant, dimeric sesquiterpenoid shizukaol B (SKB) inhibited expression of several adhesion molecules, such as intercellular adhesion molecule-1 (ICAM-1), vascular cell adhesion molecule-1 (VCAM-1) and E-selectin, in HL-60 and human umbilical vein endothelial (HUVEC) cells, suggesting that shizukaol B might inhibit monocytes adhesion to endothelial cells, which was a critical step in the pathogenesis of atherosclerosis (Kwon et al., 2006). Except this data, there were no reports on the pharmacological or biological activity of SKB until now. In this study, we investigated immunosuppressive activity of SKB and demonstrated that SKB might induce apoptosis-mediated immunosuppression. Of note was that SKB preferentially in-

www.biomolther.org

Open Access DOI: 10.4062/biomolther.2011.19.1.059

pISSN: 1976-9148 elSSN: 2005-4483

Copyright $\odot 2011$ The Korean Society of Applied Pharmacology duced apoptosis in B cells, but not T cells, macrophages, and dendritic cells.

\section{MATERIALS AND METHODS}

\section{Materials}

Female C57BL/6 mice (6-8 weeks old) were obtained from Korea Research Institute of Bioscience and Biotechnology (Chungbuk, Korea). Mice were housed in specific pathogenfree conditions at $21-24^{\circ} \mathrm{C}$ and $40-60 \%$ relative humidity under a 12-hr light/dark cycle. All animals were acclimatized for at least 1 week prior to the experiments. The experimental procedures used in this study were approved by the Chungbuk National University Animal Experimentation Ethics Committee. The dried roots of Chloranthus japonicas Sieb. (Chloranthaceae) were extracted three times with $\mathrm{MeOH}$ at room temperature for 3 days (Kwon et al., 2006). The MeOH extract was separated into two fractions using $\mathrm{CHCl}_{3}$ as the nonaqueous phase. The $\mathrm{CHCl}_{3}$ fraction was loaded on a silica gel column (Merck, 230-400 mesh) and eluted with a step-gradient of $\mathrm{CHCl}_{3}: \mathrm{MeOH}(50: 1)$. The fraction was separated using reverse phase column chromatography (YMC-Gel ODS-A, 70-230 mesh), and eluted successively with $70 \% \mathrm{MeOH}$. The

\section{*Corresponding Author}

E-mail: shan@chungbuk.ac.kr

Tel: +82-43-261-2815, Fax: +82-43-268-2732

'These authors contributed equally to this work. 


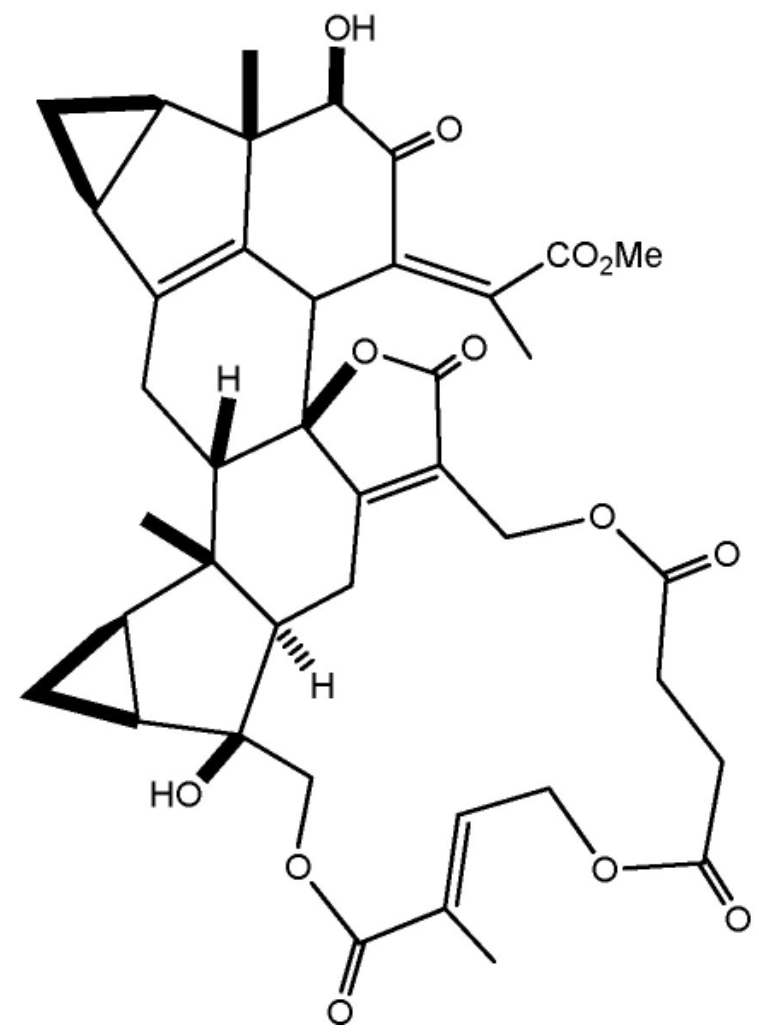

Fig. 1. Structure of SKB. fraction was subjected to semi-preparative HPLC and gave shizukaol B (SKB)(Fig. 1).

\section{Isolation of spleen cells}

Spleen cells were obtained from specific pathogen free C57BL/6 mice (female, 6-7 weeks) and were freed of red blood cells by lysis buffer treatment (Han et al., 2001). Splenic B cells were isolated by negative depletion by using biotinylated antibodies to CD4, CD8, GR-1, and CD11c (BD Pharmingen) and Dynabeads M-280 Streptoavidin (Invitrogen, Carlsbad, CA, USA). Splenic T cells were isolated by negative depletion using biotinylated antibodies to B220, GR-1, and CD11c (Han et al., 2005b). Purity was typically $>90 \%$. Cells were cultured in RPMI 1640 medium (Invitrogen, Carlsbad, CA, USA) supplemented with 10\% fetal calf serum (Hyclone, Logan, UT, USA), 2 mM L-glutamine and $50 \mu \mathrm{M}$ 2-mercaptoethanol (Sigma, St. Louis, MO, USA).

\section{Generation of primary macrophages and dendritic cells}

Bone marrow (BM) cells were obtained from femurs and tibias of C57BL/6 mice. After red blood cells were lysed, whole BM cells $\left(2 \times 10^{5}\right.$ cells $\left./ \mathrm{ml}\right)$ were cultured in $100-\mathrm{mm}^{2}$ culture dishes in $10 \mathrm{ml} /$ dish of complete medium containing $10 \mathrm{ng} / \mathrm{ml}$ M-CSF to generate primary macrophages or $2 \mathrm{ng} / \mathrm{ml}$ GM-CSF (R\&D Systems, Minneapolis, MN, USA) to make dendritic cells (DC). On day 3 , another $10 \mathrm{ml}$ of fresh complete medium containing $10 \mathrm{ng} / \mathrm{ml} \mathrm{M-CSF} \mathrm{(or} 2 \mathrm{ng} / \mathrm{ml}$ GM-CSF) was added, and half of the medium was changed on day 6 . On day 8 , nonadherent and loosely adherent cells were harvested by vigorous pipetting and used as primary macrophages or DCs (Kim et al., 2007). Primary macrophages recovered from these cultures were generally $>85 \% \mathrm{~F} 4 / 80^{+}$, but not $\mathrm{CD}^{+}$and $\mathrm{B}^{2} 2 \mathrm{O}^{+}$ (Shi et al., 2004). Cells were treated with LPS and SKB for 24
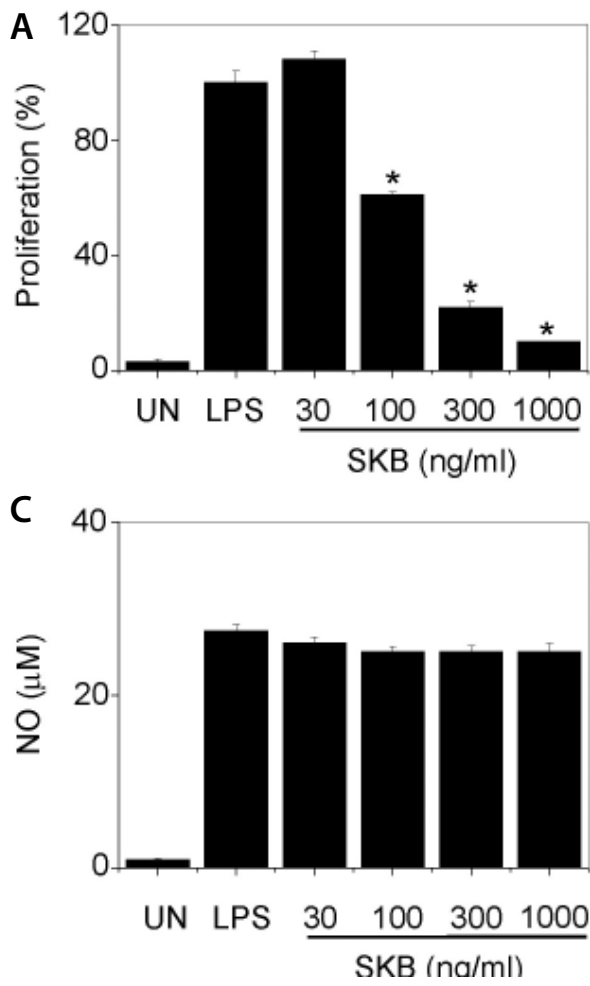
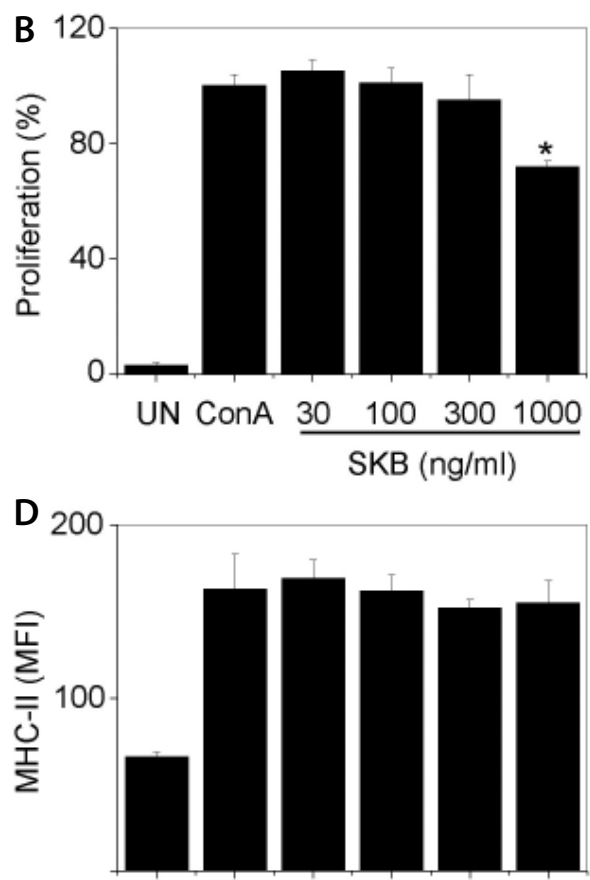

UN LPS $\frac{301003001000}{\text { SKB }(\mathrm{na} / \mathrm{ml})}$
Fig. 2. Effect of SKB on the functions of immune cells. B cells were treated with $1 \mu \mathrm{g} / \mathrm{ml}$ of LPS and/ or SKB for $72 \mathrm{~h}(\mathrm{~A})$. T cells were treated with $1 \mu \mathrm{g} / \mathrm{ml}$ of ConA and/ or SKB for $72 \mathrm{~h}(\mathrm{~B})$. Cells were labeled with $\left[{ }^{3} \mathrm{H}\right]$-thymidine for the last $18 \mathrm{~h}$ and harvested using an automated cell harvester. Primary macrophages were treated with 1 $\mu \mathrm{g} / \mathrm{ml}$ of LPS and/or SKB for 24 $\mathrm{h}$ and NO production was measured with Griess reagent (C). Dendritic cells were treated with 1 $\mu \mathrm{g} / \mathrm{ml}$ of LPS and/or SKB for $24 \mathrm{~h}$ and MHC-II expression level was measured with flow cytometer (D). Significances were determined using the ANOVA test versus LPSor ConA-treated groups $\left({ }^{*} p<0.05\right)$. 
hr. Isolated supernatants were mixed with an equal volume of Griess reagent and then incubated at room temperature for $10 \mathrm{~min}$. Nitrite production was determined by measuring absorbance at $540 \mathrm{~nm}$ versus a $\mathrm{NaNO}_{2}$-derived standard curve (Han et al., 2005a). Immature DCs (iDC) recovered from these cultures on day 8 were generally $>85 \%$ CD $11 c^{+}$, but not $\mathrm{CD}^{+}$ and $\mathrm{B}_{22} \mathrm{O}^{+}$. iDCs were treated with LPS for $24 \mathrm{hr}$ to induce maturation and SKB was treated at concentrations ranging from 30 to $1,000 \mathrm{ng} / \mathrm{ml}$. Cell staining was performed using a combination of FITC-conjugated anti-MHC-II plus PE-conjugated CD11c antibodies. Cells were analyzed using a FACSCanto flow cytometer (BD Biosciences, San Jose, CA, USA), and data were analyzed using WinMdi software (Scripps, La Jolla, CA, USA). Forward and side scatter parameters were used to gate live cells.

\section{Lymphoproliferation assay}

$\mathrm{T}$ cells were activated with concanavalin A (Con A, $1 \mu \mathrm{g} /$ $\mathrm{ml}$ ) and $B$ cells were activated with lipopolysaccharide (LPS, 1 $\mu \mathrm{g} / \mathrm{ml}$ ) (Han et al., 1998). SKB was treated at concentrations ranging from 30 to $300 \mathrm{ng} / \mathrm{ml}$. Cells were pulsed with ${ }^{3} \mathrm{H}$-thymidine (113 Ci/nmol, NEN, Boston, MA, USA) at a concentration of $1 \mu \mathrm{Ci} /$ well for the last $18 \mathrm{hr}$ and harvested on day 3 using an automated cell harvester (Inotech, Dottikon, Switzerland). The amount of ${ }^{3} \mathrm{H}$-thymidine incorporated into cells was measured using a Wallac Microbeta scintillation counter (Wallac, Turku, Finland).

\section{Cytotoxicity assay}

Cell viability was examined by the propidium iodide $(\mathrm{PI})$ nuclear staining method. Cells were stained with $1 \mu \mathrm{g} / \mathrm{ml}$ of PI and analyzed with a FACSCalibur flow cytometer (BD Biosciences, San Jose, CA, USA). Cells stained with PI were con- sidered dead cells (Kim et al., 2009).

\section{Annexin $\mathrm{V}$ and propidium iodide (PI) staining assay}

Cells were treated with different concentration of SKB $(30$, 100 , and $300 \mathrm{ng} / \mathrm{ml}$ ) for $24 \mathrm{~h}$. Apoptosis of $\mathrm{T}$ and B cells was determined by Annexin V/PI apoptosis detection kit (Invitrogen, Carlsbad, CA, USA). Briefly, the cell pellet was re-suspended in PBS followed by incubation with Annexin V-conjugated with FITC and PI. The fluorescence of the cells was then analyzed with a FACSCalibur flow cytometer (BD Biosciences, San Jose, CA, USA). It could discriminate intact cells (Annexin $\left.\mathrm{V}^{-} / \mathrm{PI}^{-}\right)$, early apoptotic cells (Annexin $\left.\mathrm{V}^{+} / \mathrm{PI}^{-}\right)$, and late apoptotic/necrotic cells (Annexin $\mathrm{V}^{+} / \mathrm{PI}^{+}$) (Nagahara et al., 2002).

\section{Cell cycle analysis}

Cells were re-suspended in $75 \%$ ethanol. After centrifugation for $5 \mathrm{~min}$ at $1,000 \mathrm{rpm}$ at $4^{\circ} \mathrm{C}$, the pellet was treated with 2 $\mathrm{mg} / \mathrm{ml}$ RNase $A$ at $37^{\circ} \mathrm{C}$ for $20 \mathrm{~min}$ and stained with $50 \mu \mathrm{g} / \mathrm{ml}$ propidium iodide $(\mathrm{PI})$ containing $0.1 \%$ Triton $\mathrm{X}-100$ and 0.02 $\mathrm{mg} / \mathrm{ml}$ EDTA. Cells were then analyzed with a FACSCalibur flow cytometer (BD Biosciences, San Jose, CA, USA) (Pallardy et al., 1999).

\section{Statistics}

Data represent the mean \pm STD of more than three samples and all experiments were performed more than three times. Standard deviations (STD) were calculated using the Student's $t$ test and $p$-values were calculated using ANOVA software (GraphPad Software, San Diego, CA, USA).
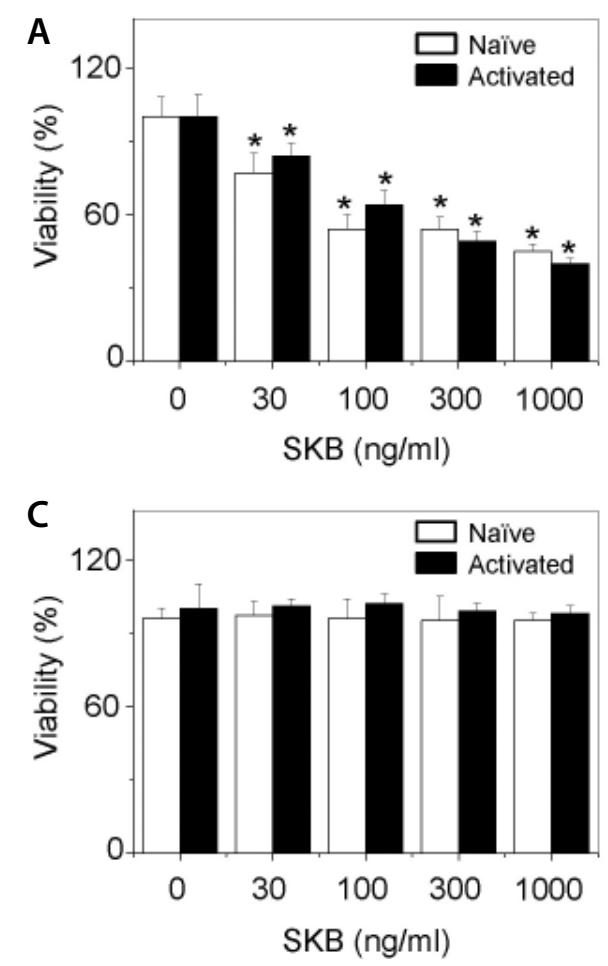
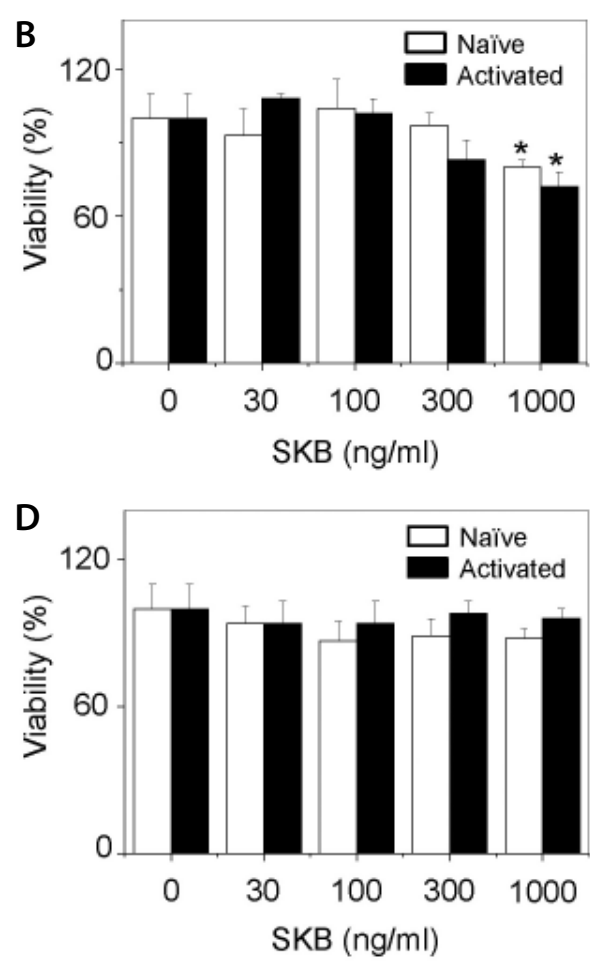

Fig. 3. Effect of SKB on the viability of immune cells. B cells (A), T cells (B), macrophages (C), and dendritic cells (D) were cotreated with LPS and SKB for 24 $h$ to examine the effect of SKB on activated cells. Or these cells were incubated with SKB alone to examine the effect of SKB on naïve cells. Cells were stained with PI and analyzed by flow cytometric assay. PI-negative cells were considered viable cells. Significances were determined using the ANOVA test versus LPS- or ConA-treated groups $\left({ }^{*} p<0.05\right)$. 


\section{RESULTS}

\section{SKB inhibits immune functions of B cells, but not T cells, macrophages, and DCs}

First, we investigated the immunosuppressive activities of SKB on several immune cells, such as B cells, T cells, macrophages, and DCs, to determine cell-type selectivity of SKB. SKB inhibited LPS-induced B cell proliferation with $\mathrm{IC}_{50}$ of 137 ng/ml (Fig. 2A). However, SKB slightly affected ConA-induced $\mathrm{T}$ cell proliferation at $1,000 \mathrm{ng} / \mathrm{ml}$ (Fig. 2B). In addition, SKB did not inhibit LPS-induced macrophage NO production (Fig. 2C) and LPS-induced MHC-II expression in DCs (Fig. 2D). These results suggested that SKB strongly affected immune functions of B cells, but slightly or not those of other immune cell types.

\section{SKB induces cytotoxicity to B cells, but not other cell types}

Next, we examined whether immunosuppressive activity of SKB was due to the cytotoxicity. Purified B cells were incubated with LPS to make activated $B$ cells or without LPS to make naïve $B$ cells. SKB was directly added to medium from the beginning of culture. SKB induced cytotoxicity to both naïve and activated $B$ cells with $\mathrm{IC}_{50}$ of 307 and $265 \mathrm{ng} / \mathrm{ml}$, respectively (Fig. 3A). However, SKB did slightly or not affect viability of $T$ cells (Fig. 3B), macrophages (Fig. 3C), and DCs (Fig. 3D). These data suggested that B cell-selective immuno- suppressive activity of SKB might be due to B cell-susceptible cytotoxicity of SKB.

\section{SKB induces apoptosis in B cells, but not T cells}

In order to determine whether $B$ cell death was due to the apoptosis-inducing activity of SKB, B cells were incubated with SKB for $24 \mathrm{~h}$ and stained with FITC-labeled Annexin V and propidium iodide (PI). Annexin $\mathrm{V}$ binds with phosphatidylserine, which becomes exposed to the outer membrane from the inner membrane during apoptosis. SKB increased annexin $V$ binding to $B$ cells (Fig. 4A, C), whereas annexin $V$ binding to T cells were not changed by SKB (Fig. 4B, C).

Phosphatidylserine exposure is believed to occur in the earlier phase of apoptotic cell death. In order to discriminate early and late apoptotic cells, we stained cells with annexin $V$ and $\mathrm{PI}$ from 6 to $24 \mathrm{~h}$. SKB increased early apoptotic B cells (annexin ${ }^{+} \mathrm{Pl}^{-}$) from $14 \%$ to $26 \%$ at $6 \mathrm{~h}$ after SKB treatment (Fig. 5A). Twenty-four hours after SKB treatment, late apoptotic $B$ cells (annexin ${ }^{+} \mathrm{Pl}^{+}$) were strongly increased from $22 \%$ to $47 \%$. However, SKB did not affect annexin $\mathrm{V}$ binding to $\mathrm{T}$ cells from 6 to $24 \mathrm{~h}$ (Fig. 5B). Overall, these results suggested that SKB induced apoptosis in B cells, but not T cells.

\section{SKB induces B cell cycle arrest at sub- $\mathbf{G}_{1}$}

Apoptotic cells show a reduced DNA staining by $\mathrm{PI}$, lower than that of $G_{0} / G_{1}$ cells (sub- $G_{1}$ peak). This was due to the DNA fragmentation, which allowed small fragmented DNA to diffuse
A
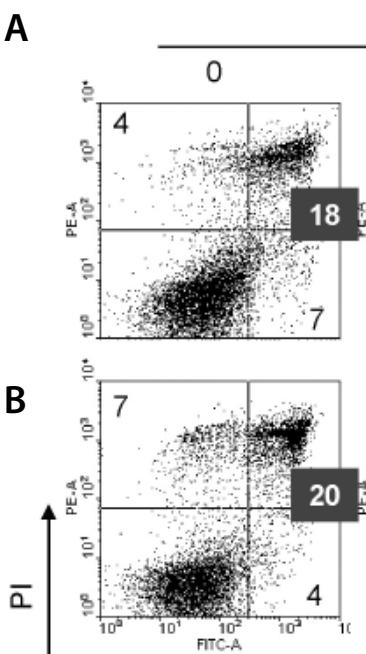

$\mathrm{SKB}(\mathrm{ng} / \mathrm{ml})$
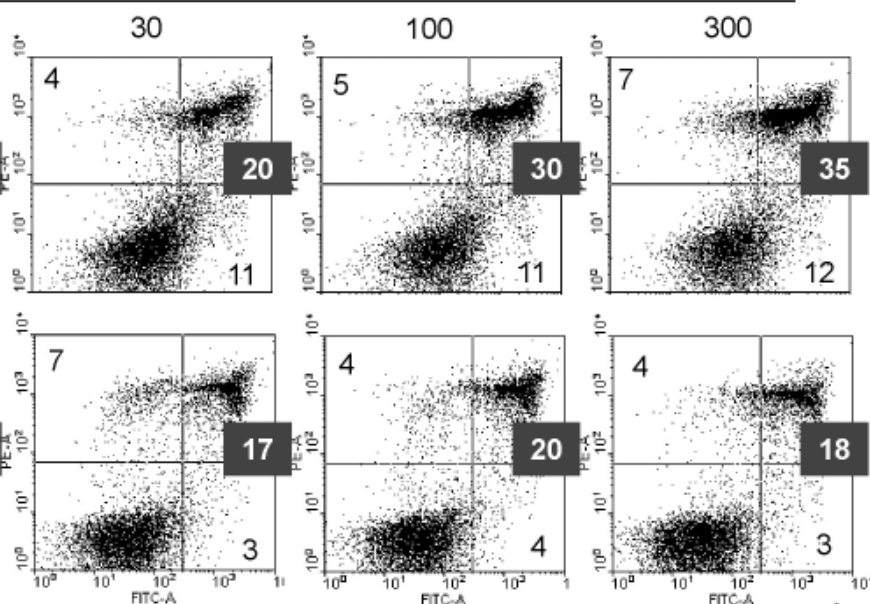

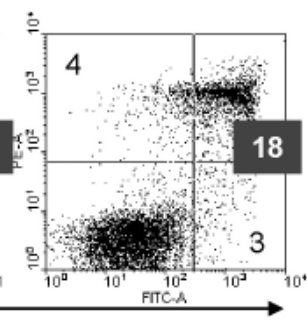

Annexin V-FITC

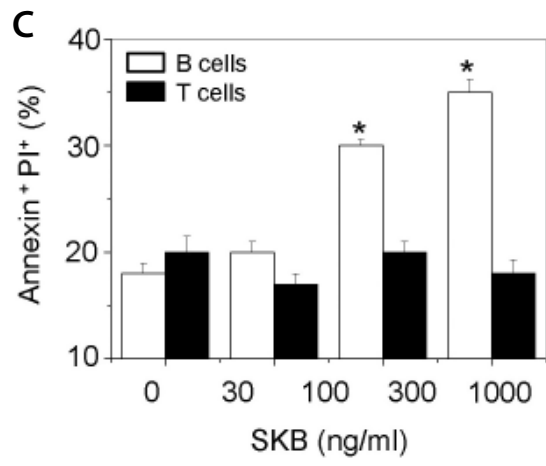

Fig. 4. Induction of $B$ cell apoptosis by SKB. $B$ cells $(A)$ and T cells (B) were treated with SKB for $24 \mathrm{~h}$ and stained with annexin V-FITC and PI. Annexin V-and PI-positive cells were considered apoptotic cells. Representative dot plots $(A$ and $B)$ and mean $\pm S D(C)$ of three-independent experiments are shown. Significances were determined using the ANOVA test versus SKB-untreated groups $\left({ }^{*} p<0.05\right)$. 
A
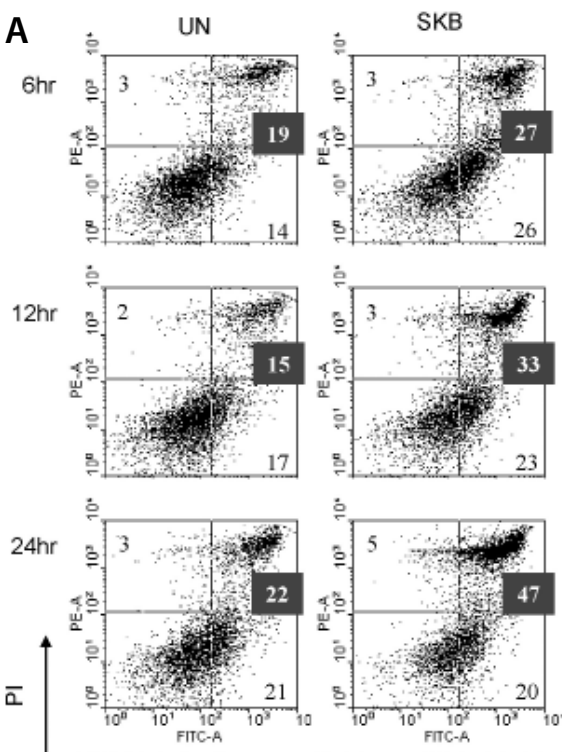

Annexin V-FITC
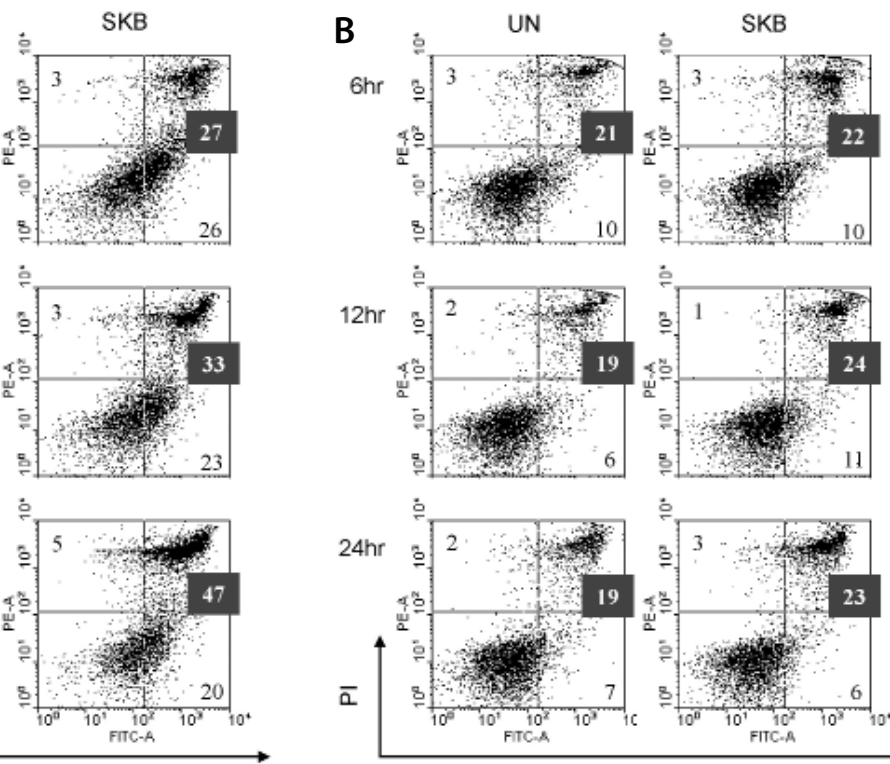

$24 \mathrm{hr}$

$\bar{a}$

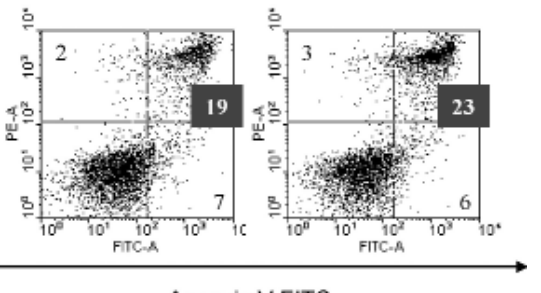

Fig. 5. Early and late apoptosis of $B$ cells induced by SKB. B cells (A) and $T$ cells $(B)$ were treated with SKB from $6 \mathrm{~h}$ to $24 \mathrm{~h}$ to examine separately early and late apoptosis. After incubation for 6,12 , and $24 \mathrm{~h}$, cells were stained with annexin V-FITC and PI. Annexin $\mathrm{V}$-positive and $\mathrm{PI}$-negative cells were considered early apoptotic cells. Annexin V-positive and PIpositive cells were considered late apoptotic cells. Representative dot plots of three-independent experiments are shown.

\section{SKB $(\mathrm{ng} / \mathrm{ml})$}
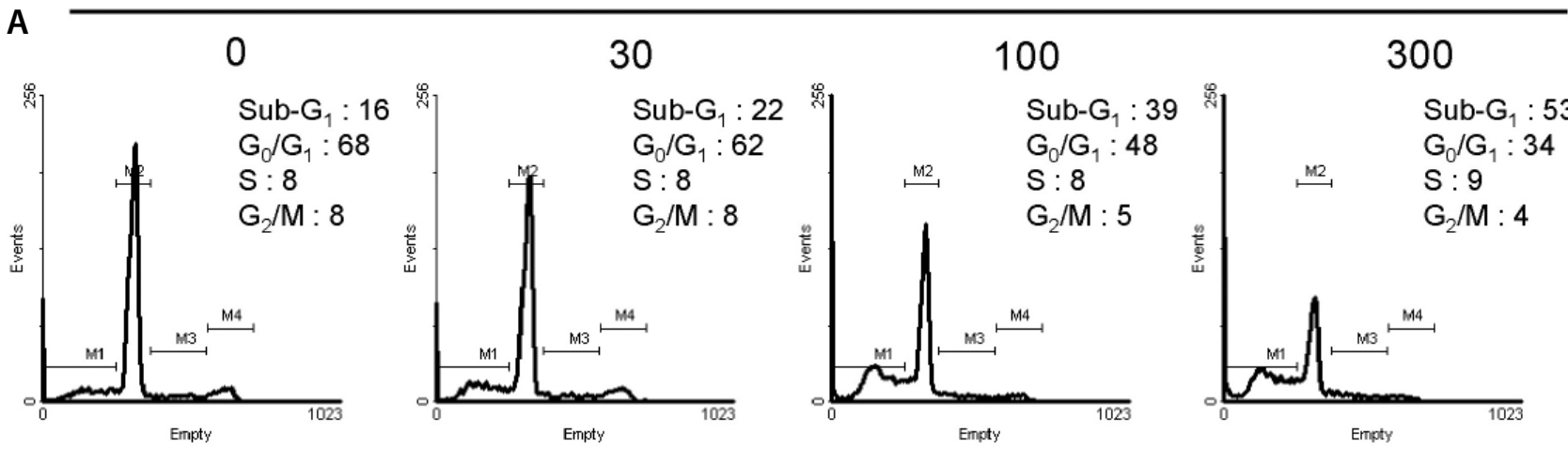

B

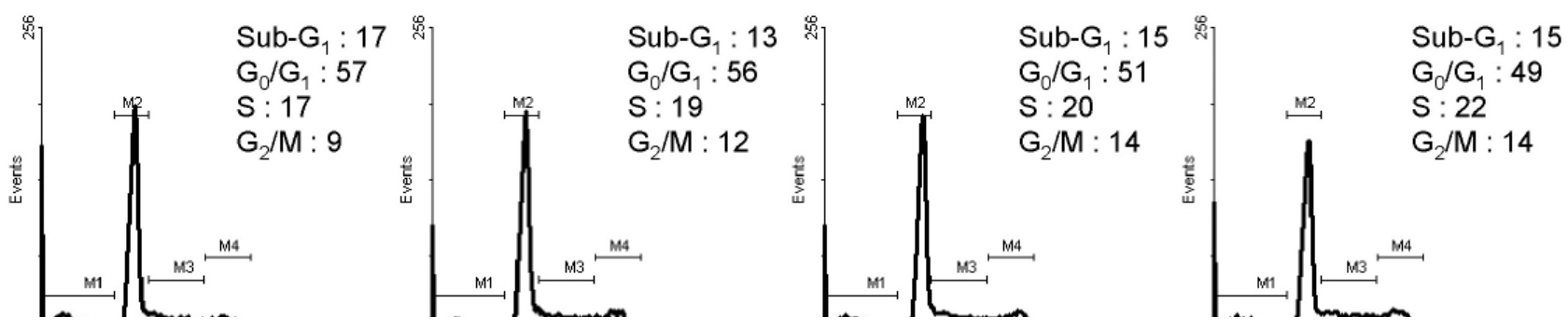

Fig. 6. Effect of SKB on cell cycles. B cells $(A)$ and T cells $(B)$ were treated with SKB from $24 \mathrm{~h}$, re-suspended in $75 \%$ ethanol, and stained with $50 \mu \mathrm{g} / \mathrm{ml} \mathrm{PI}$ containing $0.1 \%$ Triton X-100 and $0.02 \mathrm{mg} / \mathrm{ml}$ EDTA. Cells were then analyzed with a FACSCalibur flow cytometer. Representative histograms of three-independent experiments are shown. $M 1$ : sub- $G_{0}, M_{2}: G_{0} / G_{1}, M_{3}: S$, and $M_{4}: G_{2} / M$ phase of cell cycle.

out through cell membrane-permeabilized by ethanol treatment during experiment. As shown in Fig. 6A, SKB increased sub- $G_{1}$ peak in $B$ cells. However, SKB slightly increase $S$ peak in $T$ cells without affecting sub- $G_{1}$ peak (Fig. $6 B$ ).

\section{DISCUSSION}

The immune system is now recognized as a target organ for the adverse effects of many agents including drugs and chemicals. Immunotoxic molecules may lead to two main types of effects: immunosuppression, which may result in an increased susceptibility to tumors or infectious diseases, and dysregula- 
tion of the immune response, leading to hypersensitivity and autoimmunity (Pallardy et al., 1999). One way to investigate the harmful effects of different chemicals is to study apoptosis in immune cells (Nagarkatti et al., 2010). Assessment of apoptosis relied on morphological and biochemical modifications of the dying cells. Apoptosis is characterized by cell shrinkage, nuclear condensation, changes in cell membrane and mitochondria, DNA fragmentation, and protein degradation by caspases (Duffin et al., 2010).

In this study, we investigated B cell apoptosis induced by natural compound SKB. A notable change in plasma membrane of SKB-treated B cells was observed. Preservation of plasma membrane integrity is one of the major characteristics of apoptosis (Schutz et al., 2009). Loss of phospholipid asymetry, with exposure of phosphatidylserine residues normally maintained exclusively in the inner leaflet, is an early and widespread phenomenon (Nagahara et al., 2002). Annexin $\mathrm{V}$, in the presence of $\mathrm{Ca}^{2+}$, preferentially binds to negatively charged phosphatidylserine and this property is used to quantify apoptosis by flow cytometry (Duffin et al., 2010). Uptake of PI appears in late stages of apoptosis triggered in vitro and denotes the secondary necrosis of dying cells which are not engulfed as they would be in vivo. We showed here that SKB increased annexin $V$ binding to $B$ cells, which suggested that SKB-treated B cells lost phospholipid asymmetry and exposed phosphatidylserine to outer membrane of cells. Apoptotic cells analyzed with classic methods for cell cycle determination show a reduced DNA staining by DNA-intercalating dyes such as PI, lower than that of G0/G1 cells (sub-G1 peak) (Williams, 2004). SKB also reduced DNA staining with PI and accumulated cells at sub-G1 stage. This phenomenon is generally assumed to be due to the generation of DNA fragments that, following ethanol permeabilization of the plasma membrane, can diffuse though this altered membrane and lower total DNA content. It has also been suggested that this effect may be explained by a reduced accessibility of the dye to condensed chromatin. Whatever the exact mechanism, analysis of this sub-G1 peak by flow cytometry has the advantages of being simple and quantitative as the percentage of cells with reduced stainability in a given population can be measured accurately (Pallardy et al., 1999).

In summary, we demonstrated here that SKB might induce apoptosis-mediated immunosuppression by targeting susceptibly B cells, but not $T$ cells, macrophages and dendritic cells. These data suggest that SKB might be used in anti-B cell therapy, since B cell depletion with anti-CD20 antibodies has become an accepted second line modality of therapy for patients with autoimmune diseases, such as rheumatoid arthritis, lupus, and diabetes (Basten, 2010). However, we could not clarify in this study why B cells were more susceptible to SKB than other cells, which required the continuous efforts to identify molecular mechanism and target proteins interacting with SKB in B cells.

\section{ACKNOWLEDGMENTS}

This work was supported by the research grant of the Chun- gbuk National University in 2009.

\section{REFERENCES}

Basten, A. (2010) The role of B cells in transplantation and immunopathic diseases. Immune. Netw. 10, 81-84.

Duffin, R., Leitch, A. E., Fox, S., Haslett, C. and Rossi, A. G. (2010) Targeting granulocyte apoptosis: mechanisms, models, and therapies. Immunol. Rev. 236, 28-40.

Han, S. B., Kim, H. M., Kim, Y. H., Lee, C. W., Jang, E. S., Son, K. H., Kim, S. U. and Kim, Y. K. (1998) T-cell specific immunosuppression by prodigiosin isolated from Serratia marcescens. Int. J. Immunopharmacol. 20, 1-13.

Han, S. B., Lee, C. W., Yoon, Y. D., Lee, J. H., Kang, J. S., Lee, K. H., Yoon, W. K., Lee, K., Park, S. K. and Kim, H. M. (2005a) Prevention of arthritic inflammation using an oriental herbal combination BDX1 isolated from Achyranthes bidentata and Atractylodes japonica. Arch. Pharm. Res. 28, 902-908.

Han, S. B., Moratz, C., Huang, N. N., Kelsall, B., Cho, H., Shi, C. S., Schwartz, O. and Kehrl, J. H. (2005b) Rgs1 and Gnai2 regulate the entrance of $B$ lymphocytes into lymph nodes and B cell motility within lymph node follicles. Immunity 22, 343-354.

Han, S. B., Park, S. H., Jeon, Y. J., Kim, Y. K., Kim, H. M. and Yang, K. H. (2001) Prodigiosin blocks T cell activation by inhibiting interleukin-2Ralpha expression and delays progression of autoimmune diabetes and collagen-induced arthritis. J. Pharmacol. Exp. Ther. 299, 415-425.

Kim, J. Y., Kang, J. S., Kim, H. M., Kim, Y. K., Lee, H. K., Song, S., Hong, J. T., Kim, Y. and Han, S. B. (2009) Inhibition of phenotypic and functional maturation of dendritic cells by manassantin a. J. Pharmacol. Sci. 109, 583-592.

Kim, J. Y., Yoon, Y. D., Ahn, J. M., Kang, J. S., Park, S. K., Lee, K., Song, K. B., Kim, H. M. and Han, S. B. (2007) Angelan isolated from Angelica gigas Nakai induces dendritic cell maturation through toll-like receptor 4. Int. Immunopharmacol. 7, 78-87.

Kuang, H., Xia, Y., Yang, B., Wang, Q. and Lu, S. (2008) Sesquiterpene glucosides from Chloranthus japonicus sieb. Chem. Biodivers 5, 1736-1742.

Kuang, H. X., Xia, Y. G., Yang, B. Y., Wang, Q. H. and Lu, S. W. (2009) Lignan constituents from Chloranthus japonicus sieb. Arch. Pharm. Res. 32, 329-334.

Kwon, O. E., Lee, H. S., Lee, S. W., Bae, K., Kim, K., Hayashi, M., Rho, M. C. and Kim, Y. K. (2006) Dimeric sesquiterpenoids isolated from Chloranthus japonicus inhibited the expression of cell adhesion molecules. J. Ethnopharmacol. 104, 270-277.

Nagahara, Y., Ikekita, M. and Shinomiya, T. (2002) T cell selective apoptosis by a novel immunosuppressant, FTY720, is closely regulated with Bcl-2. Br. J. Pharmacol. 137, 953-962.

Nagarkatti, M., Rieder, S. A., Vakharia, D. and Nagarkatti, P. S. (2010) Evaluation of apoptosis in immunotoxicity testing. Methods. Mol. Biol. 598, 241-257.

Pallardy, M., Biola, A., Lebrec, H. and Breard, J. (1999) Assessment of apoptosis in xenobiotic-induced immunotoxicity. Methods 19, 36-47.

Schutz, C., Fischer, K., Volkl, S., Hoves, S., Halbritter, D., Mackensen, A. and Fleck, M. (2009) A new flow cytometric assay for the simultaneous analysis of antigen-specific elimination of T cells in heterogeneous T cell populations. J. Immunol. Methods 344, 98-108.

Shi, G. X., Harrison, K., Han, S. B., Moratz, C. and Kehrl, J. H. (2004) Toll-like receptor signaling alters the expression of regulator of $\mathrm{G}$ protein signaling proteins in dendritic cells: implications for $\mathrm{G}$ protein-coupled receptor signaling. J. Immunol. 172, 5175-5184.

Williams, O. (2004) Flow cytometry-based methods for apoptosis detection in lymphoid cells. Methods Mol. Biol. 282, 31-42. 